Article

\title{
Embeddedness as a Differentiating Element of Indigenous Entrepreneurship: Insights from Mexico
}

\author{
Ericka Molina-Ramírez ${ }^{1}$ and Virginia Barba-Sánchez ${ }^{2, *(D)}$ \\ 1 Escuela Superior de Comercio y Administración, Instituto Politécnico Nacional, Plan de San Luis, s/n, \\ Santo Tomas, Miguel Hidalgo, Ciudad de México 11340, Mexico; emolinar@ipn.mx \\ 2 Department of Business Science, University of Castilla-La Mancha, ESII, Paseo de los Estudiantes, s/n, \\ 02006 Albacete, Spain \\ * Correspondence: virginia.barba@uclm.es; Tel.: +34-967-599-200
}

Citation: Molina-Ramírez, E.;

Barba-Sánchez, V. Embeddedness as a Differentiating Element of Indigenous Entrepreneurship: Insights from Mexico. Sustainability 2021, 13, 2117. https://doi.org/10.3390/su13042117

Academic Editor: María de la Cruz del Río-Rama

Received: 20 January 2021

Accepted: 10 February 2021

Published: 16 February 2021

Publisher's Note: MDPI stays neutral with regard to jurisdictional claims in published maps and institutional affiliations.

Copyright: (c) 2021 by the authors. Licensee MDPI, Basel, Switzerland. This article is an open access article distributed under the terms and conditions of the Creative Commons Attribution (CC BY) license (https:// creativecommons.org/licenses/by/ $4.0 /)$.

\begin{abstract}
The present work aims to know the motives of why Indigenous entrepreneurs start companies, as well as how the characteristics of these groups influence the motives for company creation and determine entrepreneurial behavior. Through qualitative research, using interviews from five Indigenous entrepreneurs in Mexico, and the comparative case studies, this research identifies the motivators and characteristics of Indigenous entrepreneurs, as well as community embeddedness as an element of core business, without which company creation could not happen. The results show that embeddedness, identity, comunalidad (communal way of life), and worldview contribute positively to entrepreneurial project achievements, which also impact the community itself. Recommendations for different economic and social agents, concerning supporting the sustainability of Indigenous communities, and the protection of their culture and historical legacies, are derived from this study.
\end{abstract}

Keywords: indigenous entrepreneurship; embeddedness; worldview; comunalidad; motivators

\section{Introduction}

Indigenous entrepreneurship (IE) is an emerging topic within social entrepreneurship and general entrepreneurship literature; thus, few studies have analyzed the characteristics surrounding the creation of Indigenous companies [1,2]. Therefore, we suggest that, "theories developed to explain entrepreneurial behavior are not adequate for understanding IE" [3] (p. 366). Little has been explored about Indigenous entrepreneurship embeddedness of indigenous entrepreneurship, as a proper dimension of this type of entrepreneurship $[2,4,5]$.

Writers, such as Foley [5], Bodle, Brimble, Weaven, Frazer, and Blue [6], point out the differences in Indigenous entrepreneurship characteristics compared to other entrepreneur groups, which are not solely from country-to-country, but from region-to-region. As Dana [2] concludes, one must take into account the cultural perception of opportunity as a variable that triggers entrepreneurship - that is, culture has a strong impact on the creation of companies. In this sense, Tipu and Sarker [7] (p. 141) claim "the proposed model posits that a more flexible and emergent approach is needed in light of the changing economic and socio-cultural realities of an Indigenous context", which is relevant in Indigenous entrepreneurship model proposals. Meanwhile Brueckne et al. [8] suggest that these types of companies not only bring economic benefits, but environmental and sociocultural benefits as well. Meis-Mason et al. [9] demystify the belief that collectivist approaches hinder the Indigenous economic benefits of enterprises. Therefore, "the Indigenous entrepreneurship spirit often relates to notions of community-based economic development" [10] (p. 15). Hindle and Lansdowne [11] (p. 132) define Indigenous entrepreneurship as "the creation, management, and development of new ventures by Indigenous people for the benefit of Indigenous people". 
In reference to embeddedness, Coleman [12] talks about the structure of social relations and the resources embedded in it. From that point of view, economic action and social performance are linked; hence, Indigenous entrepreneurship groups have been studied that reflect their behavior in economic activities, according to the culture and characteristics of their ethnic groups. Dana and Smyrnio [4] (p. 594) discuss the Sami ethnic group, which is influenced by its own characteristics, such as "social ties resulting in a network of mutual obligations through genetic and social kinship, association and solidarity, dialogue and consensus, and responsibility to the earth and spirits". This special vision of social relations has important implications for entrepreneurial projects. Bodle et al. [6] consider culture and Indigenous identity as valuable intangible assets that influence entrepreneurship, which could also interfere with the elements that characterize the community itself [13].

In this context, the research focuses on the indigenous entrepreneurial profile in Mexico, to achieve the above, the following structure is presented. In the following section, we review the embeddedness concept, worldview, and identity in Mexico (regarding Indigenous embeddedness and its characteristics). In Section 2, we describe the empirical methodology applied, as well as the population object of the study, specifically the companies created by Indigenous groups in five Indigenous towns in Mexico. Subsequently, we expound on the cases studied, and carry out a qualitative analysis using Atlas TI software. Finally, we describe the discoveries and research conclusions, including future lines of research and recommendations to institutions to support Indigenous communities.

\section{Embeddedness, Worldview, and Identity of Indigenous Groups}

The embeddedness concept has its origins in social theory; James Coleman [12] is the major exponent of the concept of social capital theory. According to this theory, the embeddedness concept consists of resources embedded in the structure of social relations (network). However, Polanyi [14] already used that term to describe the economic relations embeddedness in social relations. Gómez [15] (p. 148) realizes the importance of this concept; its theoretical and semantic meaning can be found in his article "Reflexiones sobre el concepto embeddedness", with the purpose of including the theoretical use within social sciences.

\subsection{Embeddedness}

In social capital theory, the notion of "embeddedness social" represents situations where economic actions and behaviors are linked and/or depend on institutions and non-economic activities, such as culture, social networks, politics, and religion [16] (p. 504).

The social structure is formed by social network links through embeddedness formation as a key element of it, as well as cohesion, integration, and social [17] and emotional support [18]. Emotional support can be manifested in happiness, satisfaction, or yielding; these emotions are influenced by embeddedness $[17,19,20]$. The relevance of this concept stem from the fact that it can be a motivator that triggers entrepreneurship.

Regarding Indigenous groups, embeddedness is given by identification and belonging to the community. Generally, the Earth is a key factor and is considered "Mother" (who gives life)—so is the dynamic living system made up of the indivisible communities of all life systems and living beings, interrelated, interdependent, and complementary, sharing a common destiny. Mother Earth is considered sacred to nations worldwide and to the original Indigenous people (i.e., by providing natural resources). Thus, actions, as well as positive (or negative) impacts will have consequences on other living beings, which means that social, political, and economical actions have a worldview [21].

In support of the above, some studies show the existence of "social ethnic solidarity; [ ... ] supported by the traditional values, norms, and structures of the social community" concerning Indigenous enterprises [22].

In conclusion, embeddedness is a key element of social structure. In the case of Indigenous groups, it is characterized by the identity that belongs to the community (from the Indigenous worldview). 


\subsection{Worldview}

According to Medina-Hernández [23] (p. 73), the worldview definition depends on the language spoken; e.g., "in English the concept worldview, [has] more restricted implications than cosmovisión".

The worldview of Indigenous communities is characterized by embeddedness within the geographic place of origin. Its principles are based on the worldview thought, understood "as a conception of society by means of the characteristics and properties of its environment [ ... ] "Each worldview implies a specific conception of human nature" [23] (p. 79). In the collective imaginary of Indigenous thought is "human's relationship with the earth, good and evil, heaven and hell, light and darkness, two united components, inherent in being, spiritual and material" [24] (p. 30).

Worldview is "the whole" in Indigenous groups; therefore, Indigenous people and cultures manifest their worldview from "thought", which is represented in the life cycle, from birth to death, through social life and community relationships [25]. Worldview also includes religious Indigenous beliefs.

Worldview is perceived as "a structured ensemble and relatively congruent by different ideological systems with which a social entity aims to learn rationally the universe" [26] (p. 472). According to [27], it means, "the conception that members of a society have about characteristics and properties of their environment is the view of the individual person in a specific society in relation to the whole, its world interpretation is the idea of the universe. Each worldview, add, involve a specific conception of human nature". According to Redfield [28], the meaning of worldview is considered the community's tangible asset, which materializes in the life cycle of the individual.

This is why worldview is so important to Indigenous communities, because of its intimate relationship "to religion, politics, economic and environment" [29]. According to Zolla and Zolla Márquez [29] (p. 37), "in cosmological systems of Mexican Indigenous the tradition has an enormous weight"; therefore, it refers to knowledge created, shared, and transmitted. When practiced, it is reworked or modified in new ways [25].

According to Danna and Smyrnios [4], Indigenous entrepreneurship is holistic because it considers economic and non-economic objectives, including cultural values, social/cultural self-determination, and heritage preservation. Thus, these dimensions are considered in the original Mexican community's worldview. Therefore, it is important to incorporate worldview to obtain knowledge about Indigenous organizations [30].

In summary, worldview refers to the set of beliefs that a society has about its environment and the universe (this includes ideological-religious systems). These beliefs or ideologies-considered intangible goods-depend on the ethnic groups. Moreover, worldview is given by the rooted in the geographic region of the Indigenous group.

\subsection{Identity and Comunalidad}

Identity is an essential element for Indigenous people to be considered-identifiedintegrated into a community, territory, or "the creation". The Indigenous entrepreneurship spirit is often related to notions of economic development in a community. For example, "any Indigenous community has the following elements: (a) A territorial space, demarcated and defined by possession; (b) A common story passing on from mouth to mouth and from one generation to the next; (c) A variant of the people's language, from which the common language is identified; (d) An organization that defines the political, cultural, social, civil, economic and religious; and (e) A communal system of procuring and administering of justice" [31] (p. 38).

In this case, the community is explained using the comunalidad concept and consists of elements that "guarantee its understanding such as 1 . The Earth as a Mother and territory, 2. The consensus in the Assembly to make a decision, 3. Free service as an authority exercise, 4. Collective work, as an act of recreation and 5. Rites and ceremonies as an expression of communal flair" [32] (p. 60). Where work is rooted in communal life, as MezaBernal [33] explains, work is given in a community assembly by means of decision; "work 
in position systems through coordination, work as reciprocity through tequio [the work done in community] by means construction and work".

A previous way of work was described as comunalidad, meaning "style of life and reason to be [ ... ] that the State should respect and preserve. [ ... ] With comunalidad we refer to daily life" [34] (p. 39) of the Indigenous community.

For Indigenous communities, comunalidad is related to the value of responsibility; every day, the comunalidad is lived in this type of organization, so it is institutionalized by the means of the type of organization, with tequios (or positions) being the most important forms of participation in the assembly. Therefore, positions come together with every individual, along with reciprocity towards the community [35]. In this way, the comunalidad manifest in "mechanisms of cooperation, collaboration, and reciprocity (intra community). This occurs at the level of people and families, as [today for you, tomorrow for me], and for the benefit of the community- such as the position system or community works (tequio, faena, or fajina). To make a decision, it is processed in the community, through the community assembly" [21]. Regarding identity, it is the being of the Indigenous person, it is its root, it is characterized by its place of origin, the territory to which it belongs, and an element of identification-integration-belonging. Embeddedness and identity go hand-in-hand.

\subsection{Indigenous Entrepreneurship}

According to [36], Indigenous entrepreneurship is a form of social entrepreneurshipa solution to social and economic problems [37] by providing social [38] and economic value. In regards to Indigenous enterprises, the common good is sought and, as a consequence of it, economic gains can be obtained [39]. From this perspective, social entrepreneurship contributes to the achievement of sustainable development goals (SDG), by encouraging economic development [36] and providing sustainable communities [40].

Literature that focuses on Indigenous entrepreneurship topics is recent (e.g., Foley and O'Connor [41]; as well as Dana [42] as a forerunner). The various works on this subject, focusing on a complex context, contribute toward an emerging theme in business creation literature. However, in the early 2000s, this concept did not exist in business literature [43]. Hindle and Lansdowne [11] (p. 132) defined Indigenous entrepreneurship "as the creation, management, and development of new ventures by Indigenous people for the benefit of Indigenous people."

One of the principal contributions that has identified Indigenous entrepreneurship is the word conducted by Peredo et al. [10]. The authors discuss the particular characteristics of this type of entrepreneurship: embeddedness with heritage and culture of its ethnicity, earth, land, as well as active participation in entrepreneurial initiative and development. Concerning Indigenous social entrepreneurship: "the fact that they are only managed by Indigenous peoples who share a common worldview. Indigenous social entrepreneurship emphasizes the creativity, innovation, and risk-taking of entrepreneurship while prioritizing the social over economic benefits" [44] (p. 4). We should note that, concerning Indigenous social entrepreneurship, this coincides with the social entrepreneur looking after the social values that a company can give to the community, rather than the economic value it can provide to the entrepreneur personally [45]. In most cases, decision-making about Indigenous entrepreneurship has been a democratic process (meaning, collectivity is a primary value) [46]. Recent research [47] has found that entrepreneurship adds value to human capital.

Other Indigenous entrepreneurship characteristics include the importance of embeddedness and identity - focusing on world vision and oneself (as an individual), and by being part of the community, territory, and in touch with one's origins. However, Gallagher and Selman [13] suggest that this type of entrepreneurship can go against Indigenous entrepreneurship, because the results can contravene with the community characteristics (i.e., the entrepreneur could be considered a "sellout"). Nevertheless, this social activity can be attractive to people "that are proud of their Indigenous heritage and committed to strengthening their communities, $(\ldots$ ) besides to being an element to rebuild their 
economies and strengthen their capacity as nations that want to reduce their dependence on agencies and government" [13] (p. 90).

The Indigenous entrepreneurial spirit is closely related to the economic development base in the community [36], as well as cultural values, where work is involved in every moment of communal life accomplished in the communal assembly through a decision [33]; furthermore, it is motivated by the family and land to which it belongs [48].

Dana [2] (p. 165) expands on culture: "There is rich heterogeneity among Indigenous peoples, and some of their cultural values are often incompatible with the basic assumptions of mainstream theories of entrepreneurship". This was created in western culture as a capitalist economic model. Thus, Indigenous communities incline toward social entrepreneurship, because these values contribute toward thinking as a unit [49]. Moreover, there is a great difference between neoliberal economic models and Indigenous values. The first is oriented toward "economic growth and export orientation, contrary to the cultural worldview of Indigenous peoples" [50] (p. 12). Definitively, Indigenous entrepreneurship often has non-economic explanatory variables, such as egalitarianism, exchange, and communal activity, contrary to capitalism, a neoliberal model [2]. In addition, Indigenous entrepreneurship can be a key element to combat poverty, obtain development in these communities, and give them identity [39].

Similarly, differences have been found on western entrepreneurship [4]. Therefore, Indigenous social entrepreneurship is an emerging topic that can contribute to a new paradigm in entrepreneurship $[2,11,51]$.

Anderson and Giberson [52] considered it a challenge to achieve an ideal approach to entrepreneurship literature in an Indigenous context; especially because the difference is based on entrepreneurship with communal values, the link between entrepreneurship and land, achievements without economic profitability, decisions based on common benefit $[4,10]$, and others. However, it is a fertile field for contributions that current researches can provide [53].

In summary, what characterizes Indigenous communities are their cultural and social values, where embeddedness and economic development in social life are rescued, and importance is placed on cultural aspects [54]. These elements are key in directly influencing cooperative entrepreneurship projects. Our conclusion, which is in line with previous studies [55], is that collectivist cultures value group interests more than individual interests [56].

Consequently, it can be affirmed that, in the bosom of Indigenous communities, entrepreneurship differs from other forms of business [57], mainly in terms of business context [13].

\section{Research Problems and Methodology}

To analyze the reality of social factors immersed in the research theme on Indigenous entrepreneurs, and the lack of previous works in this specific field, a qualitative methodology was chosen, according to the following research questions.

What motivated Indigenous entrepreneurs to create a company?

According to the question posed, an attempt is made to "understand culture and society" as Danna and Smirniof [4] (2013, p. 595) exposed, retaking to Crozier and Friedber [58]. For this reason, they propose a qualitative research strategy in this type of inquiry, arguing that an interpretative-inductive approach is correct. Foley and $\mathrm{O}^{\prime}$ Connor [36] (p. 281) expound that the phenomena (little treated from the field of academic production) must be inductive. Finally, Hindle [59] (p. 578) presents qualitative methods for entrepreneurial research and contribution to this field:

"A well-structured approach to the problem of matching the research technique to the research question will specify which techniques of investigation (the choice-ofmethods problem) are appropriate to what key questions in the field (ontological problem) and give reasons why (the axiological and epistemological problems)". 
With the above, we understand that Indigenous groups have their own characteristics and, in turn, very different experiences than other entrepreneurs. Thus, identifying Indigenous entrepreneurs is rare; therefore, in agreement with Hindle [59], a qualitative methodology approach to study Indigenous entrepreneurship in Mexico is correct.

According to the authors, the chosen methodology has been qualitative, through multiple or comparative cases [60,61]. From this methodological position, Bygrave [62] (p. 17) notes that, in the history of science, emerging paradigms rarely follow a sequence of the classical thesis. In our case, Indigenous entrepreneurship is a theory in development to which it is intended to contribute.

According to Gioia, Corley, and Hamilton [63] (p. 16): "Studying social construction processes implies that we focus more on how organization members go about constructing and understanding their experience and less on the number or frequency of measurable occurrences". Accordingly, with the aforementioned, and due to the particular study problem that is being analyzed, it is important to highlight case studies within the qualitative methodology, which allow obtaining deep knowledge of the subject matter by contextualizing it in its reality $[61,64]$. The heterogeneity that may exist in Indigenous communities [2], demonstrated by Foley and $\mathrm{O}^{\prime}$ Connor [41] in their research on social capital and networks of Indigenous entrepreneurs, is a great reason to support the methodology presented. Precisely, the ultimate purpose of this is the analysis of the reality of cases concerning the characteristics of entrepreneurship in Indigenous communities. Therefore, in accordance with the research design, the technique for obtaining information has been in-depth interviews.

For the selection of cases, three sources were used, Comisión Nacional de los Pueblos Indígenas (CDI), Red Indígena de Turismo de México A.C., and the international nongovernmental organization Echoway. These organizations have databases of Indigenous ecotourism companies in Mexico. The information has been obtained through the web pages of these organizations.

Subsequently, a snowball-type sampling of the cases was made, with five cases to study. In the absence of official statistics, the five selected cases (chosen by the snowball sampling technique) are representative of the group of Mexican Indigenous entrepreneurs of ecotourism based on the Indigenous group and their legal status.

Indigenous entrepreneurs of these cases were contacted by telephone (to make appointments with them) and then in-person interviews were conducted. The interviews were conducted with a guide, using semi-structured questions. In order for the informants to provide all of the data that they wanted, the objective was to obtain as much information as necessary regarding the topic being investigated. Moreover, the interviews were recorded and transcribed word-for-word.

Transcripts were processed using the Atlas TI v7 software (software for qualitative analysis attended by CAQDAS computer), to facilitate data analysis.

Each case study was contextualized to Indigenous groups belonging to the companies that were studied, located in rural environments in Indigenous communities in Mexico. Given the characteristics of this social entrepreneurial phenomenon itself, the individual characteristics of an entrepreneur are systematically related to firm-level behavior and outcomes. Thus, we used multiple levels of analysis: individual and firm. For the analysis of the data, it was decided to utilize a cross-data analysis to know the general characteristics of entrepreneurship in Indigenous communities, with categorical analysis, using Atlas TI v7. Based on the methodology of the grounded theory [65], and to cover the scientific methodological rigor of the qualitative analysis, open coding and categorization were utilized to finish the content analysis. Table 1 summarizes the above. 
Table 1. Technical datasheet of the study.

\begin{tabular}{ll}
\hline Target population of study (universe) & Indigenous ecotourism companies \\
\hline Geographic scope & Mexican national territory \\
\hline Analysis units & Multiple levels: entrepreneur and business \\
\hline Number of Cases & Five \\
\hline Method & Qualitative analysis \\
\hline Information collection strategy & Interview \\
\hline Information analysis technique & Content analysis categorization \\
\hline Information analysis tool & Atlas TI v7 \\
\hline Interviewed & Founding partner of Indigenous ecotourism \\
\end{tabular}

Source: own elaboration.

\section{The Case Studies}

The case studies of this research enhance particular characteristics of Mexican Indigenous communities, such as lack of employment or opportunities; and the differential problems, similar to other countries, such as Australia [66] or Canada [67]. The interview was the principal tool that provided information. The interviewees were founding partners of five companies dedicated to ecotourism and/or cultural tourism.

As Croce [3] affirms, there are characteristics (in the Indigenous context) that differ according to the continent and nation in which one belongs; this means, in terms of culture, there are elements that do not allow for generalization. That is why we are contextualizing the case studies in this document.

In Mexico's case, one's Indigenous ethnic language is just one of the characteristics of the people to which one belongs; however, maintaining it is not an essential key factor for ethnic continuity. Indigenous groups are governed by their own authorities and local customs, their justice systems allow them to resolve their trouble in the community bosom, looking for a balance with the cosmos [68].

It is important to highlight that, in Mexico, there are 68 Indigenous languages, of which, 12 have the largest number of speakers): Náhuatl, Maya, Tseltal, Mixteco, Tsotsil, Zapoteco, Otomí, Totonaco, Chol, Mazateco, Huasteco y Mazahua [68] (p. 3).

The present study considered the importance of this community in Mexico, Latin America, and around the world, as well as indicators, such as percentage of illiteracy $(23 \%)$, population without access to health $(15.9 \%)$, population without drinking water $(12.8 \%)$, and lack of income (or less than €2.93, per day, 28.7\%) [69].

In the case of the sample selection, two fundamental aspects were taken into account: (1) that the entrepreneurs created ecotourism companies characterized by the specific aspects of the activity; (2) were Indigenous, meaning that they joined one of the 68 Indigenous ethnic groups registered in Mexico (CDI) and maintained their language and Indigenous cultural guides [70]. Table 2 shows the case studies presented and Figure 1 can be located geographically in Mexico. 
Table 2. Characteristics of the entrepreneur and geographic location.

\begin{tabular}{|c|c|c|c|c|c|}
\hline Dimension & Case 1 & Case 2 & Case 3 & Case 4 & Case 5 \\
\hline Interviewed & Founding Partners & Founding Partner & Founding Partner & Founding Partner & Founding Partner \\
\hline $\begin{array}{c}\text { The age range of } \\
\text { the Indigenous } \\
\text { entrepreneur }\end{array}$ & $30-60$ years & $50-60$ years & 30 years & 20-30 years & 20-30 years \\
\hline Sex & Male & Male & Male & Male & Male \\
\hline Language & Nahuatl & Otomí & Nahuatl & Maya & Maya \\
\hline $\begin{array}{c}\text { Geographic } \\
\text { location }\end{array}$ & Veracruz & Hidalgo & Morelos & Campeche & Quintana Roo \\
\hline $\begin{array}{l}\text { Legal } \\
\text { form/Organization } \\
\text { form }\end{array}$ & Civil association & $\begin{array}{l}\text { Limited Liability } \\
\text { Rural Production } \\
\text { Company }\end{array}$ & None & Cooperative & Cooperative \\
\hline
\end{tabular}

Source: own elaboration.

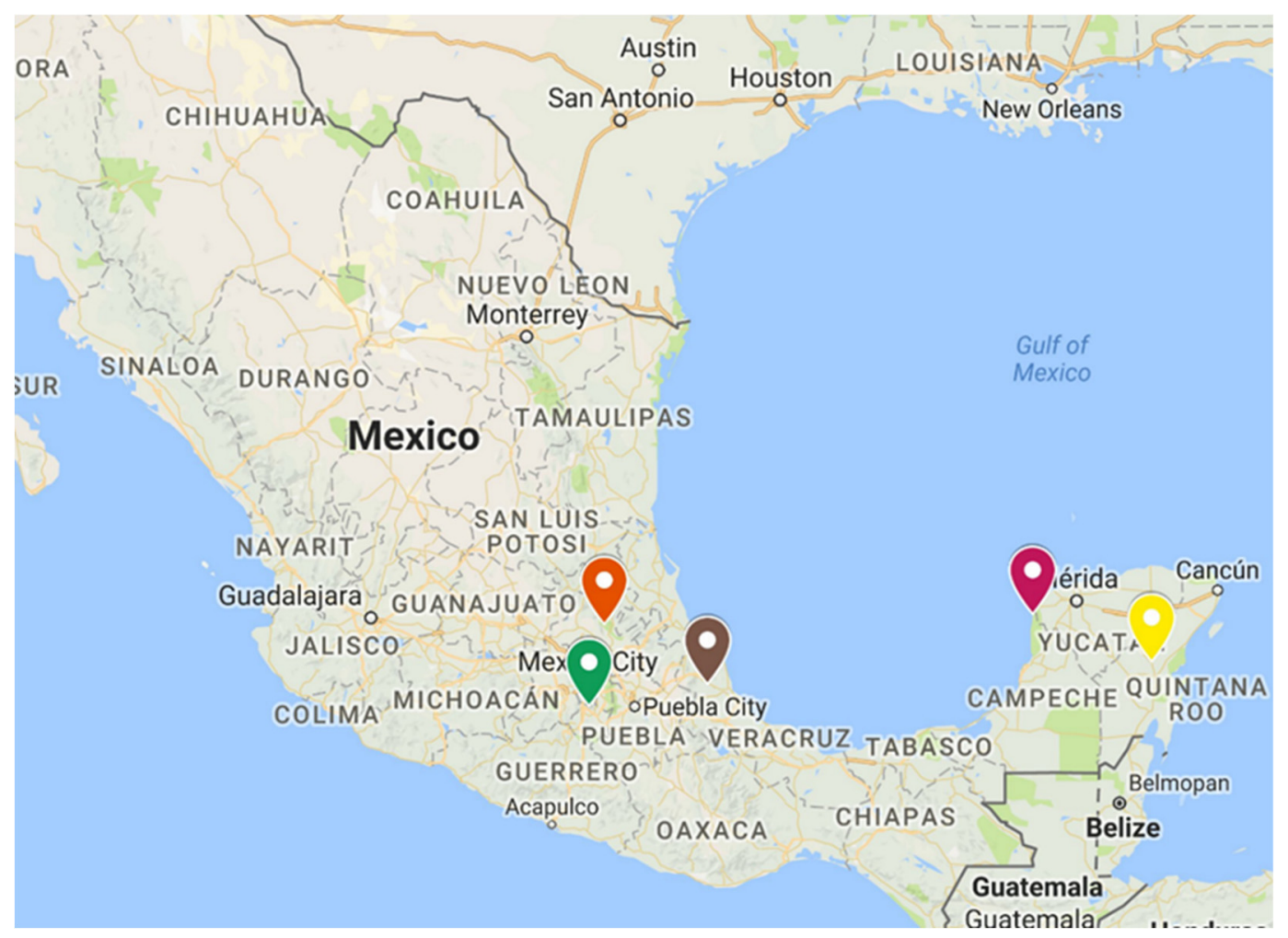

Figure 1. States of the Mexican Republic: case studies.

\subsection{Case 1}

Case 1 is a company located in an ejido in the state of Veracruz; the Indigenous language spoken in the area is Nahuatl. The initiative arises as a means to offer ecotourism services, assuming (and benefiting) from the conservation and defense of the region's natural resources, culture, and tradition. This, as manifested by its founders, reflects the love the Ejido people have for their roots and place of origin. Comuneros and ejidatarios are the owners of Ejido, which is a legal figure of association. Agrarian Law-Art. 99-100. "The law will protect the integrity of the lands of Indigenous groups. The law considering the respect and strengthening of the community life of the ejidos and communities, will protect the land for human settlement and regulate the exploitation of lands, forests and 
waters of common use and the provision of necessary actions to raise the level of life of its inhabitants".

The decision of business was born in the midst of informal meetings between residents of the Ejido community. One day the idea arose to "create a form" and expose their culture and natural resources. Case 1. is constituted as a civil association. By means of this association, the environment has been preserved and influenced in the community in a positive way, to appreciate the value and reaffirm their identity within Ejido.

“... Informally, [they met... ] consent of the Ejido Assembly had to de obtained to establish this organization ... [Case 2 particularly] it borns from the love I have for the ravine's ground that gives quality coffee and due to fall in coffee prices we abandoned them, but now it gives us another way, through people who are interested in what there is [in the Ejido] in a natural way [ ... ] exist people [in the Ejido with] mixed points of view or suspicion because what is being done isn't understood, [they don't understand] this type of projects will give them employment, assurance that things will be preserved naturally ..."

The association was formed with 21 associates, but formally, it was 20 people, and they had the support of the ejido as well as the people.

Initiating the organization was not as difficult as expected. The fact that the community was "united" was a valuable resource, manifested initially with the initiative to form the organization, and later, by seeking the support of the Ejidal Assembly, as well as support from non-members of Case 1. For this reason, and in order to retain unity (and respect authority), they decided to ask for, what they call, the support of the ejido. Nevertheless, the obstacle that was presented to them was in convincing the community that an innovative project could work, as well as making it clear that they would not misuse the region's natural resources or appropriate the ejido for other purposes.

\subsection{Case 2}

Case 2 is a rural production society of limited liability and it is located in the state of Hidalgo. In the area, the principal Indigenous ethnic is Otomi, who call themselves "Hña hñus" (otomíes). The location of Case 2 is on a mountain, apparently, but inside of it are grottos that were formed by the collapse of "the roof"; it is divided into two caves, one 90 meters deep and the other one 120 m deep.

Case 2 were created six years ago by an initiative of the municipal president. The suggested project was to create an ecotourism center in the ejido lands as a way to obtain a benefit, mainly economic, and at the same time use the natural resources. When the proposal arose, the land was abandoned. When the project began, the first thing the founding partners had to do was clean it of trash and grass.

"The company was created and [ ... ] thanks to a former municipal president who had the idea of doing as an ecotourism center, this was abandoned, there was garbage inside, some tunnels still have garbage that's the reason they continue to be cleaned, they continue to be cleaned and then thank to him the ejidatarios was convened because this is a Ejido, ejidatarios was convened and he told them the idea of making it an ecotourism center and taking advantage of it, no?...".

Thus, the municipal president convened ejidatarios and proposed the project to them. Work began-initially by means of financing provided by the local government, putting up fences, and later, the construction of the restaurant was complete.

After obtaining the first financial resources, the Ejidal Commissariat took over the project and work began. Unfortunately, at that time, the project did not work as expected, mainly because they had no knowledge of business administration or social enterprises. Due to the lack of knowledge in this sector, they did not know their competitive advantage and how to exploit it-a necessity for new companies as they must survive in competitive situations. Due to the above-mentioned, the commissary decided to create a special committee that would be in charge of the entrepreneurial project. With the decision to 
create this committee, in 2002, greater results were seen-the impact was visualized in the number of visitors to the center. For this reason, in 2004, a second committee was formed by ejidatarios. The above was the reason for the trust between the partners, and they chose to form a society to appropriately explore the ejidatarios resources. However, not all ejidatarios were in favor of the decision, but the majority supported the project (there are currently 46 partners). It is important to mention that, due to the governing characteristics of the Indigenous community, the decision makers are, for the most part, older adults (a characteristic that is reflected in the same society), and teamwork, as narrated by the founding partner:

"... The important step was the one taken by the adults [older ... ] who make up society, the youngest are we, those in their 50's. We have adults in their 80 's, who are ejidatarios and are part of the society now. They took a big step. It has been possible to build a good team, working together has been the key to success".

\subsection{Case 3}

The Indigenous entrepreneurship of this case is located in the state of Morelos. In this community, the Nahuatl language is spoken, so the natives are called nahuas. The initiative to create to Case 3. was a concept given in order to offer ecotourism products, benefiting from conservation and protecting natural resources, preservation of culture, and the tradition of Indigenous groups, mainly from the community of San Juan. This initiative was developed within the community, who saw the uncontrollable number of tourists visiting the community without control, and saw the negative impact that it had (and has) on green areas and in their community. Their ancestors also cared since nature gave them all of the resources necessary to live on. Founder Partner exposed that the main cause was environmental preservation-the main reason as to why the Case 3 group was created:

"Our motive born from we decided to preserve our environment [ ... ] our community; we see that more people come, to walk, but there is not control so that was another cause, therefore we want controlled tourism, in addition to the fact that we have also noticed who arrive take things and loot, that take away the little plant, that the stone [ ... ] in this way our resources are being extracted and we must have a control, consequently the situation was exposed in the assembly".

They organized through the community assembly, and the communal members supported the organization since 2009. They were aware of the necessity of training: "the reason for creating a company is not enough for it to be successful, they must have knowledge, aptitudes or abilities".

Since the beginning, they were aware of the above, because the principal obstacle they had to face was misinformation, but when it was explained, the community assembly accepted and passed the barrier. They accepted that the main obstacle was misinformation, but when they explained the project and objectives to the community assembly, the community accepted the project.

"The fact to give the information has opened the doors for us [ . . ] everything was done from a community assembly to explain the project and the communal members said there is no problem, we can organize, so we had the interest and we started in some way form [encourage] the project, but we knew that we needed training and for that was arranged the first [financing]".

Initially, according to the informant, the community and families did not believe in the project; they thought it would not prosper, but within the same community, there were entire families that supported the founding partners in order to make the project work.

Time had passed since the idea was thought of, and they managed to be environmental interpreters, but they could not develop it, because they could not get together. However, training was the key-the information. Case 3 started with four partners, now there are 23 members. 
As they say, it is a long way to achieve consolidation-but they persisted. Consequently, the great advantage was that their project came from, what they called, "social bases". Moreover, the project was gestated internally, so they knew "for what" and "why" they were doing it.

\subsection{Case 4}

This organization is located in Campeche. This center is attended by eight young entrepreneurs of Maya heritage; all of them originated from Ejido. The idea came in 2005, approximately, with the dream of offering ecotourism services in the Maya community. The reasons to create the organization were various; among the most important included self-employment, the local natural resources of the Maya community, the entrepreneurship of Indigenous youth, using land as a resource to be worked, as well as using raw material or essential supplies for hostelry and restoration.

Initially, the founders were dedicated to fishing as a primary activity. The community had always lived off fishing; they were innovative in having ecotourism as an emerging economic activity, which offered enough income for members of the organization to live well.

One of the founding partners describes how the project idea was conceived. He tells the story of the ecotourism center creation. At the end of their studies, the entrepreneurs came back to Isla, with the firm conviction of dedicating themselves to the traditional economic activities of the community-an activity that their ancestors practiced: fishing. As was previously mentioned, because of the environmental issues, the government did not issue permits for exploitation of local marine species, so, as visionaries, they took note of the different natural attractions that the locality had and took advantage of them as sources of income, while protecting the area and respecting its customs.

It all started as a result of their return to the locality; the young people who returned looked at exploiting fish as a way of life, because it was a traditional activity. However, since there were regulations for the protection of natural resources, and due to overexploitation in the region, permits were necessary in order to fish in the bank. This was the first reason to create the company. The second reason was to obtain an income in order to make a living (for themselves and their families).

"first of all we came back to the school, we couldn't fish, saw the natural attractions that we had. We asked help with a donation of land and it was donated to us, right? We have the facility to access the community spaces because we are people who have always lived in Isla. That is why the idea arose, we saw that we couldn't practice an activity that at the time we wanted to do; the true I think was the best because nowadays is a declining activity because the closures, that species, it's difficult fish, it's overexploited and we saw the ecotourism as a good alternative."

The founding partner explains that, after having the idea, this group of young people organized and began investing; it was an enriching experience because they could create the organization. After that, the adventure began, because they had to look for organizations that supported them and believed in them. Above all, they needed financial resources because they "lived daily" and they had no money (only what was necessary).

\subsection{Case 5}

Case 5 refers to an initiative located in the state of Quintana Roo, where the ethnic group is Maya. Quintana Roo is located in the south east of the Mexican Republic. The entrepreneurship is contextualized in an Indigenous Maya community. The Indigenous Mayan people's identity is maintained in force by the concurrence of at least three associated factors: "the daily use of Mayan language, the permanence of rituals and religious customs and the autonomous social organization of communities" [71] (p. 25).

According to the founding member, in 2002, Case 5 did not yet exist as a cooperative. Initially, a group of young people who worked in the blue lagoon began to develop the 
project when a biologist proposed to the ejidatarios of the area to participate in training courses. At that time, the members of Case 5 presented themselves and began to visualize a possible business that could give them alternative incomes and, at the same time, be sustainable. Thus, they begin by offering their services, such as interpretive hiking, visiting the cenote, swimming in the blue lagoon, camping, and kayak. After two years, the idea of diversifying the business arose, adding rural tourism, so they created the cultural route, where members of the community were invited to show their festivities, customs, and values, such as traditional food, dance, medicine, observation of meliponas bees, and storytelling.

Founder partnership said "After two years when realized that we could offer more potential and we had more potential in the community, such as [our] cultures; so I sat down and began to think about what could we do, something like tell stories, make typical food, dance, traditional medicine [make known] meliponas bees. [So] one says, my grandfather tells stories, hey! Invite him for this. So we were diagnosing, doing an analysis of everything we have in the community, then we saw that there was that".

To achieve the "cultural tour", a convincing work was carried out with community members, as they did not understand how tourists could be interested in their customs. However, it was possible to gather a group of people who offered the services of traditional Mayan food and dancers, among other activities.

When the project started, there were 10 people, but in the end, when the legal entity was established, there were eight people. From gestation to the start of operation, a year had passed. Subsequently, they saw the necessity of a legal entity to obtain financing. After establishing the cooperative, they looked for support, which came from the United Nations Development Program (UNDP), who supported it financially. With this resource, it was possible to build offices and bathrooms, and purchase bicycles and computers. The UNDP "remove[d] barriers" and was a motivation to continue with the project. As a cooperative, more tourist visits was obtained due to the formality and organization of the group.

Moreover, at Case 5, two tours are offered: the cultural and the ecotourism. In the cultural tour, they offer traditional medicine workshops, observations of meliponas, storytelling, and rope making with henequen. In regards to the second tour, an interpretive trail is offered, a visit to the cenote, swimming in the lagoon, visiting the observation tower where one can see birds, kayaking, and camping. The environmental workshops are a way for the community and tourists to understand the impact that humanity has on the environment and why it should be taken care of. Moreover, they identified the target audience for the environmental education workshop: children. The way to reach them was through schools that participated in the project, intending to preserve and value their traditions, culture, and environment.

After a lot of work, the support of ejido was obtained. The cooperative members are sons of ejidatarios, not ejidatarios, so they do not have the same rights; therefore, they need the consent of the ejido to develop their activities. Consequently, in the ecotourism tour, they are only guides; on the culture tour, as there is no exploitation of the ejido, the authorization of the Commissariat is not necessary.

“... we are ejido so ejidatarios decide, we have problems despite being ejidatarios' sons, for instance, we have some lagoons, cenotes, beautiful as you can not imagine, but nobody works it or let you work it, then the problems start. That's why we created the cultural part and the maintenance part of Laguna Azul corresponds to the ejido, we are only guides, of course, they and many people are benefited. In the community tourism, we are direct [of Case 5] because we manage the people of the community". 


\section{Discussion}

For the qualitative study, since the same type of generalization is not possible as it would be for a quantitative study, Halkier [72] establishes a specific generalization-an analytical generalization-without universalizing it (due to the context of the research). Following this author, in this work, a first review of the interviews was carried out, identifying central themes, thereby identifying the categories of analysis. On this basis, the findings were compared with the previous literature and an analytical generalization was obtained.

To analyze the cases, first, a summary of the topics studied was elaborated, such as the main differences or similarities between the investigated Indigenous entrepreneurs, according to the characteristics of the entrepreneur (language, age range, and sex), geographic location, and motive or creation element of the value of entrepreneurship. Open coding was elaborated; the categories of analysis were identified according to the information provided by the informants, and concerning the theoretical framework developed to finish with the comparison of the data in the case studies.

\subsection{Worldview, Embeddedness, and Identity}

Table 3 is a summary of the conception of entrepreneurs about worldview, embeddedness, identity (including communality), and the new company. Firstly, the decisions were always made in the community and/or Ejidal, respecting the organization, the uses, and customs of the community. The assembly is the organ of governance and authority within these communities. In the same way, embeddedness is visualized, showing that an eco-touristic center not only benefits entrepreneurs, but also the entire community, as they seek common benefits, knowing that there will be economic benefits for entrepreneurs. Moreover, in terms of improving an area, this is manifested by the informant of case 3 , who mentions that the project was born from the social bases. This can be observed in Table 3, which presents short excerpts from the transcribed interviews of the cases studied, and the data provided by the informants. In this case, we see the importance of the characteristics of Indigenous groups, such as embeddedness and identity, manifesting at the time of starting an enterprise.

Table 3. Category worldview-embeddedness-identity.

\begin{tabular}{|c|c|}
\hline Case & Answers \\
\hline Case 1 & $\begin{array}{l}\text { "... well, because we initially associate informally with adults, ejidatarios and non-ejidatarios, } \\
\text { young people, children who always get excited when something comes naturally; ... from there } \\
\text { we arrived with the great support of everyone to look for something formal, more representative } \\
\text { and that could serve us for the purposes that currently exist, we had to get the consent of the } \\
\text { Ejido Assembly". }\end{array}$ \\
\hline Case 2 & $\begin{array}{l}\text { "I always say that the older adults took a great step because they really are not going to see the } \\
\text { splendor of this, this will be seen by their children and grandchildren and we have told them } \\
\text { don't do it right now for you, do it for your children, think that when the ejido those who fought } \\
\text { him did not fight for them. At that time they fought for us and now we have to work for those } \\
\text { who come back, so they have seen it and a good team has been made with all of them, I think this } \\
\text { is the key". }\end{array}$ \\
\hline Case 3 & $\begin{array}{c}\text { "... that was another, from an assembly to explain in a way to express what we have to say [ ... } \\
\text { ] comuneros said no problem if you want we can organize. So, when we saw the interest, we could } \\
\text { somehow start making this organization. I see it as an advantage, what is being created is on its } \\
\text { own initiative [ ... ] of the social bases is being created, from there is ay is now". }\end{array}$ \\
\hline Case 4 & $\begin{array}{l}\text { "We have the facility to access the community spaces because we are people who have always } \\
\text { lived in Isla Arena. I would like to comment that it is a problem that bears all the responsibility in } \\
\text { the community because I have made awareness campaigns to the people, they have participated } \\
\text { in events that have been organized by the (Comisión Nacional de Áreas Naturales Protegidas) } \\
\text { CONANP by Ria, because we belong to the Ria reserve and they have organized beach cleaning } \\
\text { events, and I see that the people are participative". }\end{array}$ \\
\hline
\end{tabular}


Table 3. Cont.

\begin{tabular}{c} 
Case Answers \\
$\begin{array}{c}\text { "In the beginning, there were eight members, in the Laguna Azul it was almost the entire ejido, } \\
\text { about } 400 \text { people because the project reaches the ejido and everything that was charged was for } \\
\text { the ejido and gave us } 20 \% \text {. Now with our community project, those who participate in the } \\
\text { activities, who are } 26 \text { people, there are males } 23 \text { women, and } 8 \text { partners. }\end{array}$ \\
$\begin{array}{r}\text { That's why we created the cultural part and the maintenance part of Laguna Azul corresponds to } \\
\text { the ejido, we are only guides, and of course, they and many people are benefited. In community } \\
\text { tourism, we are direct because we manage the people of the community". }\end{array}$ \\
\hline
\end{tabular}

Source: own elaboration.

Table 4 shows the importance of the words revealed by the informants in the interview, in which the worldview-embeddedness-identity category is observed, which is made up of folk, support, community, families, oneself, and people. This shows the importance of this category in the entrepreneur's mind.

Table 4. Word repetitions in order of frequency.

\begin{tabular}{ccc}
\hline Order & Repetitions & Word \\
\hline 1 & 70 & Folk \\
2 & 51 & Support \\
3 & 50 & Part \\
4 & 45 & Community \\
5 & 29 & Information \\
6 & 28 & Tourism \\
7 & 27 & Project \\
8 & 26 & You \\
9 & 24 & Company \\
10 & 23 & Family \\
11 & 23 & Group \\
12 & 22 & People \\
13 & 21 & Idea \\
14 & 20 & Example \\
\hline
\end{tabular}

Source: own elaboration.

\subsection{Motives to Create the Company}

Indigenous entrepreneurship began as a project, seeking common benefits, where economic goals were not the main impulse. Even so, they managed to obtain economic gains derived from business activities.

The motives as to why Indigenous entrepreneurs started was because they wanted to preserve their environment, traditions, and culture. It is important to mention that, in case 5, it was because they saw an opportunity - they had natural resources and cultural practices that could be offered as tourist products, and they created value from them. In addition, in two cases (4 and 5), they started by only looking for self-employment, but later they realized the potential. As can be seen, entrepreneurship derives from a collectivist culture where entrepreneurs seek common benefits rather than an economic income. The Indigenous groups characterized by collective benefits demonstrated this through economic activity; they also took embeddedness and identity as the basis for achieving their objectives.

Something momentous happens in case 5. The entrepreneurs begin with the idea to create a company as a source of income (self-employment) and take advantage of the community resources, but in the training process-as they completed the requirements to start the company in a formal and legal way-they discovered the importance of taking care of the environment. In this sense, they started an "environmental workshop". This is important, because through the workshop, they can educate people on their culture and 
traditions, as well as protecting and respecting the environment. In the founding partner's words: " ... care and rescue to strengthen their cultures, care for the environment and the impact it would have on their communities..." ".

All of the above is shown in Table 5. Case 1 started, in the first instance, by invitation from the municipal president. Cases 2, 3, and 5 focused on preserving the environment. In case 5, they started by preserving tradition and culture, but took advantage of the region's resources (similar to cases 3 and 4). Finally, the necessity of self-employment led to case 4 creating the ecotourism center.

Table 5. Characteristics of the entrepreneur and geographic location.

\begin{tabular}{cccccc}
\hline Motives for Creation Value & Case 1 & Case 2 & Case 3 & Case 4 & Case 5 \\
\hline Environment & $\mathrm{X}$ & & & $\mathrm{X}$ & \\
Traditions & $\mathrm{X}$ & & $\mathrm{X}$ & & $\mathrm{X}$ \\
$\quad$ Culture & $\mathrm{X}$ & $\mathrm{X}$ & & & \\
$\begin{array}{c}\text { Resource exploitation } \\
\text { Alternate income } \\
\text { Self-employment } \\
\text { Invitation }\end{array}$ & & $\mathrm{X}$ & $\mathrm{X}$ & $\mathrm{X}$ & $\mathrm{X}$ \\
\hline
\end{tabular}

Source: own elaboration with Atlas TI.

\subsection{The Governance of Decision-Making}

At the beginning of the research, a category called "decision-making" was not considered, but after codification, this category was created, which marks the importance of governance in these types of Indigenous organizations (and impacts their creation). In this case, decision-making in Indigenous communities is carried out through "community assembly" [21]. To create their companies, Indigenous entrepreneurs had to take their projects to the decision-making bodies.

Each informant shows describes the creation process; they had to have authorization from the communal or ejido assembly. Although the people are legally governed by these figures, it is important to note that none of them overlooked mentioning it. In the five cases, they did not take for granted what they should respect the figure of the assembly, but openly stated it, which highlights the importance of joint decision-making for the creation of Indigenous companies-that is, how comunalidad impacts this new category.

\section{Conclusions and Limitations}

The main contribution of this work has been to identify the motives as to why Indigenous entrepreneurs from Mexico start businesses and analyze how the defining characteristics of these groups influence their motivations. The results show that Indigenous entrepreneurship is not derived from the same motivations as western entrepreneurship; it is closer to social entrepreneurship due to the social-cultural context where it is developed [73]. Embeddedness, identity, comunalidad, and worldview are incorporated into the practices to undertake, which are subject to the culture and values of the group to which the entrepreneurs belong. It is important to highlight that the main purpose (or motive) of entrepreneurs is to preserve the environment, take advantage of its natural resources, and make known the cultural heritage of the Indigenous community to which they belong. In the same way, they make themselves visible and show the world their values, culture, and motivation, emphasizing the worldview of their ethnic group (this is in line with work done by Peredo and McLean) [38].

In each project, the community assembly was always consulted, so decisions were made by consensus; thus, it was discovered that Indigenous entrepreneurs respect their customs, and incorporate the decision to undertake the concept of comunalidad. Moreover, the present investigation managed to reveal how Indigenous entrepreneurship is strongly embedded in the territory of the entrepreneur's ancestors, proving that Indigenous entrepreneurs seek common benefits, and that entrepreneurship is based on the 
community. The forms of cooperation, collaboration, and reciprocity in the community as a manifestation of the concept known in the literature as social capital.

In Indigenous groups, being rooted in the Earth and their ethnicities, the community can be considered the extension of the family; furthermore, it provides identity (thus, the importance of the meaning of comunalidad) [22]. Decision-making (in any area) is subject to a community assembly and a council of elders, depending on the case of the organization. Unlike the literature on western entrepreneurship, in Indigenous issues, it is important to highlight the importance of community-its territory of "the creation" as an element of its identity, a characteristic sign of collectivist cultures [30].

Embeddedness is also a factor to consider, in line with the results obtained by Wang and Altinay [74], as well as considering the comunalidad and the ethnic group, as it impacts entrepreneurship and its consolidation. This is because, in societies with collectivist organizations, it is easier to seek common benefits and achieve the main objectives (or the creation of value) that entrepreneurship provides [75]. What gives value to Indigenous entrepreneurship concerning the community (which is often a motivation to create the company) depends on the contributions to the environment, as well as care and preservation of traditions and culture.

In this way, it is also verified that Indigenous entrepreneurship, as a form of social entrepreneurship, contributes to the achievement of SDGs, by encouraging the economic development of these communities [36] once sustainable communities are built [40].

This work has certain limitations. Among them, in the same case of studies, the informants interviewed could have differences with others in Mexico as well as with other Indigenous communities of other countries. However, this is the first step toward obtaining greater findings in the future. From the epistemology, the method used in the present investigation is valid, but it does not allow generalizing; therefore, this investigation can be accomplished with quantitative and qualitative methodology, taking care of the items that may be generalizable due to differences in Indigenous communities.

In regards to future lines of research, investigations should review the barriers to entrepreneurship that this type of population faces, and compare it with that of western entrepreneurship. It should also focus on Indigenous entrepreneurship and sustainability, to create sustainable entrepreneurial models. This research, however, is focused on the micro level, but can be extended to macro levels.

The recommendations from this research mainly focus on subjects dedicated to the elaboration of public policies, because they must understand the characteristics and motivations of Indigenous entrepreneurs for the creation of programs that encourage entrepreneurship in Indigenous and/or rural areas in Mexico. It is important to know these communities in order to maximize the success of the programs implemented, and to understand where the investment projects or business plans have positive indicators in terms of sustainability.

Author Contributions: Conceptualization, E.M.-R. and V.B.-S.; methodology, E.M.-R. and V.B.-S.; validation, V.B.-S.; formal analysis, E.M.-R.; investigation, E.M.-R.; data curation, E.M.-R.; writingoriginal draft preparation, E.M.-R.; writing-review and editing, V.B.-S.; visualization, V.B.-S.; supervision, V.B.-S.; project administration, V.B.-S. All authors have read and agreed to the published version of the manuscript.

Funding: This research received no external funding.

Institutional Review Board Statement: Not applicable.

Informed Consent Statement: Not applicable.

Data Availability Statement: The data that support the findings of this study are available from the corresponding author.

Conflicts of Interest: The authors declare no conflict of interest. 


\section{References}

1. Mika, J.P.; Fahey, N.; Bensemann, J. What counts as an indigenous enterprise? Evidence from Aotearoa New Zealand. J. Enterprising Communities People Places Glob. Econ. 2019, 13, 372-390. [CrossRef]

2. Dana, L.P. Indigenous entrepreneurship: An emerging field of research. Int. J. Bus. Glob. 2015, 14, 158. [CrossRef]

3. Croce, F. Indigenous entrepreneurship, society, and the dimensions of diversity: An overview of the Canadian national context. Indigenous Afr. Enterp. 2019, 21, 359-371.

4. Dana, L.-P.; Smyrnios, K.X.; Poutziouris, P.; Goel, S. The push-pull of Indigenous Sámi family reindeer herding enterprises: A metaphor for sustainable entrepreneurship. In Handbook of Research on Family Business, 2nd ed.; Edward Elgar Publishing: Northampton, MA, USA, 2013; pp. 588-606.

5. Foley, D. An examination of indigenous Australian entrepreneurs. J. Dev. Entrep. 2003, 51, $276-296$.

6. Bodle, K.A.; Brimble, M.; Weaven, S.; Frazer, L.; Blue, L. Critical success factors in managing sustainable indigenous businesses in Australia. Pac. Account. Rev. 2018, 30, 35-51. [CrossRef]

7. Tipu, S.A.A.; Sarker, A.E. Developing an integrative dynamic framework of indigenous entrepreneurship: The case of United Arab Emirates. Int. J. Public Adm. 2020, 43, 441-451. [CrossRef]

8. Brueckner, M.; Spencer, R.; Wise, G.; Marika, B. Indigenous entrepreneurship: Closing the gap on local terms. J. Australian Indig. Issues 2014, 17, 2-24.

9. Mason, A.H.M.; Anderson, R.B.; Dana, L. Inuit culture and opportunity recognition for commercial caribou harvests in the bio economy. J. Enterp. Communities People Places Glob. Econ. 2012, 6, 194-212. [CrossRef]

10. Peredo, A.M.; Anderson, R.B.; Galbraith, C.S.; Honig, B.; Dana, L.P. Towards a theory of indigenous entrepreneurship. Int. J. Entrep. Small Bus. 2004, 1, 1-20. [CrossRef]

11. Hindle, K.; Lansdowne, M. Brave spirits on new paths: Toward a globally relevant paradigm of indigenous entrepreneurship research. J. Small Bus. Entrep. 2005, 18, 131-141. [CrossRef]

12. Coleman, J.S. Social capital in the creation of human capital. Am. J. Sociol. 1988, 94, S95-S120. [CrossRef]

13. Gallagher, B.; Selman, M. Warrior entrepreneur. Am. Indian Q. 2015, 39, 73-93. [CrossRef]

14. Polanyi, K. Traffici e Mercati Negli Antichi Imperi, 3rd ed.; Einaudi: Torino, Italy, 1978.

15. Gómez, M.Á. Reflexiones sobre el concepto de embeddedness. Polis: Investig. Análi. Sociopolítico Psicosoc. 2004, 2, 145-164.

16. Granovetter, M. Economic action and social structure: The problem of embeddedness. Am. J. Sociol. 1985, 91, 481-510. [CrossRef]

17. Kwon, H.W. A social embeddedness perspective on turnover intention: The role of informal networks and social identity evidence from South Korea. Public Pers. Manag. 2017, 46, 263-287. [CrossRef]

18. Barba-Sánchez, V.; Ramírez, E.M. Efectos del apoyo emocional de las redes cercanas al emprendedor indígena sobre el éxito de la nueva empresa ecoturística en la mitad sur de México. Cuad. Tur. 2015, 36, 79-99. [CrossRef]

19. Gibbons, D.E. Friendship and advice networks in the context of changing professional values. Adm. Sci. Q. 2004, 49, $238-262$.

20. Mossholder, K.W.; Settoon, R.P.; Henagan, S.C. A relational perspective on turn-over: Examining structural, attitudinal, and behavioral predictors. Acad. Manag. J. 2005, 48, 607-618. [CrossRef]

21. Gallardo, E. Lo público en los procesos comunitarios de los pueblos indígenas en México. Polis Rev. Latinoam. 2012, 11, 169-182. Available online: http:/ /journals.openedition.org/polis/3650 (accessed on 15 January 2020). [CrossRef]

22. Dana, L.-P.; Gurau, C.; Light, I.; Muhammad, N. Family, community, and ethnic capital as entrepreneurial resources: Toward an integrated model. J. Small Bus. Manag. 2019, 58, 1003-1029. [CrossRef]

23. Medina Hernández, A. La cosmovisión mesoamericana: Una mirada desde la etnografía. In La Cosmovisión, Ritual e Identidad de los Pueblos Indígenas de México; Broda, J., Baez-Jorge, F., Eds.; Consejo Nacional para la Cultura y las Artes: Ciudad de Mexico, Mexico, 2001; pp. 67-163.

24. Agredo Corona, G.A. El territorio y su significado para los pueblos indígenas. Revista Luna Azul 2006, $23,28-32$.

25. Vargas-Montero, G. La cosmovisión de los pueblos indígenas. In Atlas del Patrimonio Natural, Histórico y Cultural del Estado de Veracruz; Córdova-Plaza, R., Ed.; Gobierno del Estado de Veracruz: Xalapa, Mexico, 2010; pp. 105-126.

26. López-Austin, A. La cosmovisión mesoamericana. In Temas Mesoamericanos; Lombardo, S., Nalda, E., Eds.; INAH: Ciudad de Mexico, Mexico, 1996; pp. 471-507.

27. Broda, J. Introducción. In La cosmovisión, Ritual e Identidad de los Pueblos Indígenas de México; Broda, J., Baez-Jorge, F., Eds.; CONACULTA-FCE: Ciudad de Mexico, Mexico, 2001; pp. 15-45.

28. López-Hernández, J.R.; Teodoro Méndez, J. La cosmovisión indígena TzoTzil y Tzeltal a través de la relación salud-enfermedad en el contexto de medicina tradicional indígena. Ra Ximhai 2006, 2, 15-26. [CrossRef]

29. Zolla, C.; Zolla Márquez, E. Los Pueblos Indígenas de México, 100 Preguntas; UNAM: Ciudad de Mexico, México, 2004.

30. Jongwe, A.I.; Moroz, P.W.; Gordon, M.; Anderson, R.B. Strategic alliances in firm-centric and collective contexts: Implications for indigenous entrepreneurship. Economies 2020, 8, 31. [CrossRef]

31. Díaz, F. Comunidad y comunalidad. In Florentino Díaz Escrito. Comunalidad, Energía Viva del Pensamiento Mixe: Colección Voces Indigenas; Robles-Hernández, S., Cardoso-Jiménez, R., Eds.; UNAM/Programa Universitario México Nación Multicultural: Ciudad de Mexico, México, 2007.

32. Nava-Morales, E. Comunalidad: Semilla teórica en crecimiento. Cuad. Sur. 2013, 18, 57-69.

33. Meza-Bernal, I. Lengua y cosmovisión. Elementos de resistencia y comunalidad en tres comunidades mayas: Macehuales de Quintana Roo. Cult. Represent. Soc. 2012, 7, 96-135. 
34. Guerrero-Osorio, A. La comunalidad como herramienta: Una metáfora espiral. Cuad. Sur. 2013, 34, 39-56.

35. Maldonado Alvarado, B. Comunalidad y responsabilidad autogestiva. Cuad. Sur. 2013, 18, 21-28.

36. Barba-Sanchez, V.; Molina-Ramirez, E. Social entrepreneurship in Mexico. In Social Enterprise-Context-Dependent Dynamics in a Global Perspective; Laratta, R., Ed.; Intech: London, UK, 2016; pp. 59-78.

37. Mair, J.; Martí, I. Social entrepreneurship research: A source of explanation, prediction, and delight. J. World Bus. 2006, 41, 36-44. [CrossRef]

38. Peredo, A.M.; McLean, M. Indigenous development and the cultural captivity of entrepreneurship. Bus. Soc. 2013, 52, 592-620. [CrossRef]

39. April, W.I.; Itenge, D.I. Fostering indigenous entrepreneurship amongst San people: An exploratory case of Tsumkwe. Int. J. Bus. Glob. 2020, 24, 496-512. [CrossRef]

40. Vázquez-Maguirre, M. Building sustainable rural communities through indigenous social enterprises: A humanistic approach. Sustainability 2020, 12, 9643. [CrossRef]

41. Foley, D.; O'Connor, J. Social capital and the networking practices of indigenous entrepreneurs. J. Small Bus. Manag. 2013, 51, 276-296. [CrossRef]

42. Dana, L.P. The origins of self-employment in ethno-cultural communities: Distinguishing between orthodox entrepreneurship and reactionary enterprise. Can. J. Adm. Sci. 1997, 14, 52-68. [CrossRef]

43. Moroz, P.W.; Hindle, K. Entrepreneurship as a process: Toward harmonizing multiple perspectives. Entrep. Theory Pract. 2011, 36, 781-818. [CrossRef]

44. Farrelly, T. Indigenous community-based ecotourism as Indigenous Social Entrepreneurship (ISE): Sounds good, but what about culture-specific human-environment relationships? In Proceedings of the Devnet Conference 2010, Palmerston North, New Zeeland, 1-3 December 2010; Available online: https:/ / devnet.org.nz/devnet-2010/ (accessed on 15 January 2020).

45. Hlady-Rispal, M.; Servantie, V. Deconstructing the way in which value is created in the context of social entrepreneurship. Int. J. Manag. Rev. 2018, 20, 62-80. [CrossRef]

46. Ahmad, A.B. A review on development of social entrepreneurship projects among indigenous People. Int. J. Psychosoc. Rehabil. 2019, 23, 1335-1342. [CrossRef]

47. Tretiakov, A.; Felzensztein, C.; Zwerg, A.M.; Mika, J.P.; MacPherson, W.G. Family, community, and globalization: Wayuu indigenous entrepreneurs as n-Culturals. Cross Cult. Strat. Manag. 2020, 27, 189-211. [CrossRef]

48. Wennecke, C.W.; Jacobsen, R.B.; Ren, C. Motivations for Indigenous island entrepreneurship: Entrepreneurs and behavioral economics in Greenland. Isl. Stud. J. 2019, 14, 43-60. [CrossRef]

49. Dana, L.P.; Light, I.H. Two forms of community entrepreneurship among reindeer herding entrepreneurs in Finland. Entrep. Reg. Dev. 2011, 23, 331-352. [CrossRef]

50. Hernandez, G. Indigenous perspectives on community economic development: A North-South conversation. Can. J. Nonprofit Soc. Econ. Res. 2013, 4, 6-24. [CrossRef]

51. Hindle, K.; Moroz, P. Indigenous entrepreneurship as a research field: Developing a definitional framework from the emerging canon. Int. Entrep. Manag. J. 2009, 6, 357-385. [CrossRef]

52. Anderson, R.B.; Gilberson, R.J. Aboriginal entrepreneurship and economic development in Canada: Thoughts on current theory and practice. In Ethnic Entrepreneurship: Structure and Process; Stiles, C.H., Galbrait, C.S., Eds.; Elservier: Amsterdam, The Netherlands, 2003; pp. 141-167.

53. Hindle, K. Contrasting Indigenous entrepreneurship in Australia and Canada: How three applied research perspectives can improve policy and programs. Small Enterp. Res. 2005, 13, 92-106. [CrossRef]

54. Cahn, M. Indigenous entrepreneurship, culture and micro-enterprise in the Pacific Islands: Case studies from Samoa. Entrep. Reg. Dev. 2008, 20, 1-18. [CrossRef]

55. Pinillos-Costa, M.J.; Reyes-Recio, L.E. Influencia de la cultura individualista-colectivista en la creación de empresas. In Proceedings of the XX AEDEM Annual Meeting, Palma de Mallorca, Spain, 5-7 June 2007; pp. 652-666.

56. Hofstede, G. Dimensionalizing cultures: The Hofstede model in context. Online Read. Psychol. Cult. 2011, 2, 8. [CrossRef]

57. Barba-Sánchez, V.; Molina-Ramírez, E. Entrepreneurship as a survival-seeking strategy for indigenous communities. In Handbook of Research on Innate Leadership Characteristics and Examinations of Successful First-Time Leaders; IGI Global: Hershey, PA, USA, 2014; pp. 398-420.

58. Crozier, M.; Friedberg, E. L'acteur et le Système; Seuil: Paris, France, 1977.

59. Hindle, K. Choosing qualitative methods for entrepreneurial cognition research: A canonical development aproach. Entrep. Theory Pract. 2004, 28, 575-607. [CrossRef]

60. Eisenhardt, K.M. Building theories from case study research. Acad. Manag. Rev. 1989, 14, 532-550. [CrossRef]

61. Yin, R.K. Case Study Reasearch. Design and Methods; SAGE: London, UK, 2002.

62. Bygrave, W. The entrepreneur ship paradigm (I): A philosophical look at its research methodologies. Entrep. Theory Pract. 1989, $14,7-26$.

63. Gioia, D.A.; Corley, K.G.; Hamilton, A.L. Seeking qualitative rigor in inductive research. Organ. Res. Methods 2012, 16, 15-31. [CrossRef]

64. Baxter, P.; Jack, S. Qualitative case study methodology: Study design and implementation for novice researchers. Qual. Rep. 2008, $134,544-559$. 
65. Glaser, B.; Strauss, A. The Discovery of Grounded Theory; Aldine Press: Chicago, IL, USA, 1967.

66. Furneaux, C.; Brown, K. Indigenous entrepreneurship: An analysis of capital constraints. In Proceedings of the Fourth AGSE International Entrepreneurship Research Exchange 2007, Brisbane, Australia, 6-9 February 2007; pp. 669-682.

67. Gallagher, B.; Lawrence, T.B. Entrepreneurship and indigenous identity: A study of identity work by indigenous entrepreneurs in British Columbia. Int. J. Entrep. Small Bus. 2012, 17, 395. [CrossRef]

68. Navarrete Linares, F. Los Pueblos Indígenas de México. Pueblos Indígenas del México Contemporaneo; CDI-PNUD: Ciudad de Mexico, Mexico, 2008.

69. INEGI. Estadísticas a Propósito del Día Internacional de los Pueblos Indígenas; INEGI: Aguascalientes, Mexico, 2016.

70. Hernández, H.H.; Chávez, A.M. La definición de la población indígena en el censo de población del año 2000 en México. In Los Indios de México en el Siglo XXI; Hernández, H.H., Ed.; UNAM Centro Regional de Investigaciones Multidisciplinares: Cuernavaca, Mexico, 2007; pp. 15-24.

71. Ruz, M.H. Mayas: Primera Parte; CDI-PNUD: Ciudad de Mexico, Mexico, 2006.

72. Halkier, B. Methodological practicalities in analytical generalization. Qual. Inq. 2011, 17, 787-797. [CrossRef]

73. Maguirre, M.V.; Portales, L.; Bellido, I.V. Indigenous social enterprises as drivers of sustainable development: Insights from Mexico and Peru. Crit. Sociol. 2017, 44, 323-340. [CrossRef]

74. Wang, C.L.; Altinay, L. Social embeddedness, entrepreneurial orientation and firm growth in ethnic minority small businesses in the UK. Int. Small Bus. J. Res. Entrep. 2011, 30, 3-23. [CrossRef]

75. Mika, J.P.; Warren, L.; Foley, D.; Palmer, F.R. Perspectives on indigenous entrepreneurship, innovation and enterprise. J. Manag. Organ. 2017, 23, 767-773. [CrossRef] 